\title{
Plasma glucagon and glucagon-like immunoreactive components in Type 1 (insulin-dependent) diabetic patients and normal subjects before and after an oral glucose load
}

\author{
A. Rovira, F. J. Garrote, J. M.Pascual, M. G. Salvador, J. L. Herrera Pombo and I. Valverde \\ Fundación Jiménez Díaz, Universidad Autónoma de Madrid, Madrid, Spain
}

\begin{abstract}
Summary. Biogel P-30 filtration of plasma from Type 1 (insulin-dependent) diabetic patients and normal subjects in basal state and after an oral glucose load was assayed with a C-terminal $(30 \mathrm{~K})$ and a glucagon-like immunoreactivity-crossreacting antiserum (R8). Up to four immunoreactive peaks of approximate molecular sizes of $>20,000$ (fraction I), 9000 (fraction II), 3500 (fraction III) and 2000 (fraction IV) were detected with the two antisera in both groups. In the basal state, the only significant difference observed between both groups was a higher R8-reactivity in fraction II in the group of diabetic patients, although the $\mathrm{R} 8$ minus $30 \mathrm{~K}$ values for this fraction did not show a significant difference between both groups. After glucose the only significant differences were an increase of R8-reactivity in fraction II in both groups ( $p<$ 0.01 ) and a decrease of $30 \mathrm{~K}$-reactivity in fraction III (IRG ${ }^{3500}$ ) in normal subjects $(p<0.05)$. In seven out of 12 diabetic patients, $30 \mathrm{~K}$-reactivity in fraction II $\left(\right.$ IRG $\left.^{9000}\right)$ and III $\left(\operatorname{IRG}^{3500}\right)$
\end{abstract}

increased above their basal values. The gut-glucagon-like immunoreactivity response to oral glucose $(\Delta \mathrm{R} 8-\Delta 30 \mathrm{~K}$ values in fraction II) was similar in both the diabetic and normal subjects. These results indicate that (1) the paradoxical rise in plasma immunoreactive glucagon after oral glucose in diabetic patients may be due to an increase of both IRG $^{3500}$ and/or $I_{R G^{9000}}$, (2) the gut-glucagon-like immunoreactivity released during glucose absorption has a molecular weight of approximately 9000 , and (3) no differences in plasma gut-glucagonlike immunoreactivity were observed in Type 1 diabetic patients when compared with normal subjects, either in the basal state or after glucose ingestion.

Key words: Plasma glucagon immunoreactivity, plasma glucagon-like immunoreactivity, Type 1 diabetes, oral glucose tolerance test, plasma gel filtration.
It has been extensively documented that plasma glucagon, measured with C-terminal antibodies, is not suppressed by oral glucose in diabetes mellitus, and, in some instances, a paradoxical increase has been observed [1-6]. On the other hand, oral glucose stimulates the secretion of intestinal glucagon-like immunoreactivity (GLI) and there are two reports of elevated basal plasma gut-GLI in Type 1 diabetic patients [3, 7], with a greater than normal response to glucose load [3]. The complexity of circulating glucagon immunoreactivity is well known in terms of variety of immunoreactive glucagon (IRG) peptides, which are recognized by antibodies directed towards the carboxi-terminal portion of glucagon, and GLI peptides that react only with antibodies directed to the central and amino-terminal portion of the glucagon molecule [8].

The aim of the present study was to clarify: (1) the nature of circulating glucagon-immunoreactive peptides in Type 1 diabetes, (2) which GLI components are responsible for the plasma rise after oral glucose load and (3) whether there is, indeed, a lack of suppressibility of glucagon (3,500 daltons) by glucose in these patients. For this purpose, we have compared the chromatographic patterns on Biogel P-30 columns, obtained with the two types of glucagon antisera (C- and $\mathrm{N}$-terminal), of basal and post-glucose plasma samples from a group of Type 1 diabetic patients with those from a group of normal subjects.

\section{Subjects and methods}

\section{Subjects}

Twelve Type 1 diabetic patients were studied (Table 1). Their mean age was $24 \pm 2$ years (six males, six females). Four were diagnosed recently and had not started insulin therapy. The remainder were on insulin treatment with a combination of intermediate- and short-acting insulins (Insulin Monotard and Actrapid Novo, Denmark) two or three times daily for 2-10 years; two were out-patients with basal blood glucose $<7 \mathrm{mmol} / \mathrm{l}$, and six were in-patients because of a recent episode of ketoacidosis. None of the patients presented with ketosis at the time of the test. All were free of diabetic complications, having normal renal function and a body mass index of $21.0 \pm$ $1.1 \mathrm{~kg} / \mathrm{m}^{2}$ for men and $21.2 \pm 1.1 \mathrm{~kg} / \mathrm{m}^{2}$ for women (mean $\pm \mathrm{SEM}$ ). 
Table 1. Clinical characteristics of the subjects.

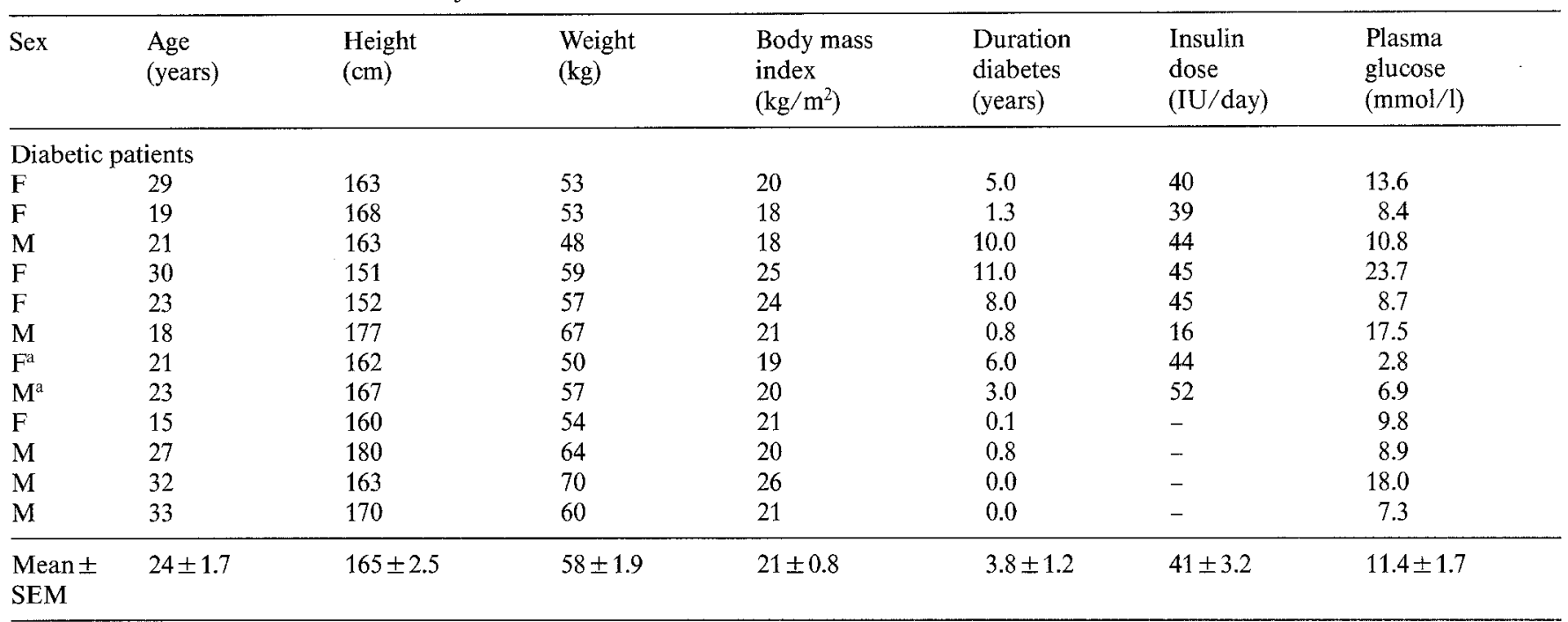

Control subjects

\begin{tabular}{llllll}
$\mathrm{F}$ & 22 & 165 & 62 & 23 & 4.7 \\
$\mathrm{~F}$ & 22 & 155 & 47 & 20 & 4.7 \\
$\mathrm{M}$ & 21 & 174 & 66 & 22 & 3.9 \\
$\mathrm{M}$ & 21 & 182 & 62 & 19 & 3.5 \\
$\mathrm{~F}$ & 27 & 164 & 57 & 21 & 4.2 \\
$\mathrm{M}$ & 21 & 182 & 77 & 20 & 4.3 \\
$\mathrm{~F}$ & 22 & 165 & 61 & 21 & 4.4 \\
$\mathrm{M}$ & 22 & 189 & 82 & 23 & 4.7 \\
$\mathrm{M}$ & 23 & 181 & 68 & 21 & 3.7 \\
$\mathrm{M}$ & 25 & 184 & 88 & 26 & 5.0 \\
$\mathrm{M}$ & 26 & 170 & 69 & 24 & 5.4 \\
$\mathrm{M}$ & 21 & 178 & 74 & 23 & 4.2 \\
\hline Mean \pm & $23 \pm 0.6$ & $174 \pm 2.9$ & $68 \pm 3.2$ & $22 \pm 0.6$ & $4.4 \pm 0.1$ \\
\hline
\end{tabular}

a Out-patients

Twelve healthy subjects with a mean age of $23 \pm 1$ years, a mean body mass index of $22.3 \pm 0.8 \mathrm{~kg} / \mathrm{m}^{2}$ for men and $21.3 \pm 0.6 \mathrm{~kg} / \mathrm{m}^{2}$ for women, and no familial history of diabetes mellitus, were studied as controls.

\section{Oral glucose tolerance test}

All the subjects received a glucose load of $1.75 \mathrm{~g} / \mathrm{kg}$ body weight at $09.00 \mathrm{~h}$ after a 12 -h overnight fast. The insulin dose was withheld on the morning of the test. The study was approved by the Hospital Ethical Committee and the patients gave their informed consent to partake.

\section{Methods}

Blood samples. Thirty minutes after placing a Butterfly needle in an antecubital vein, blood samples were obtained every $15 \mathrm{~min}$ at basal conditions for $30 \mathrm{~min}$. After the oral glucose load, blood samples were obtained at 15 -min intervals during the first $90 \mathrm{~min}$ and every $30 \mathrm{~min}$ for the following $90 \mathrm{~min}$.

Blood was collected in chilled tubes containing aprotinin ( $500 \mathrm{KIU} / \mathrm{ml}$, Trasylol, Bayer, Química Farmaceutica, Barcelona, Spain) and EDTA $(1 \mathrm{mg} / \mathrm{ml})$ and maintained at $4^{\circ} \mathrm{C}$. After the test, plasma was separated by centrifugation at $1500 \mathrm{~g}$ for $20 \mathrm{~min}$ at $4^{\circ} \mathrm{C}$, and subsequently kept at $-20^{\circ} \mathrm{C}$.

Plasma chromatography. Basal and post-glucose (a pool from 30 to $90 \mathrm{~min}$ ) plasma samples $(3 \mathrm{ml})$ were filtered on Biogel P-30 columns $(50 \times 1 \mathrm{~cm}$, Bio-Rad Laboratories, Richmond, California, USA) and eluted with $\mathrm{NH}_{4} \mathrm{HCO}_{3}(50 \mathrm{mmol} / 1, \mathrm{pH} 8.8)$. Tracer amounts of radioactive molecular weight markers, ${ }^{125} \mathrm{I}-\mathrm{Na}$ (Amersham International, Amersham, Bucks, UK), ${ }^{125} \mathrm{I}$-insulin and ${ }^{125} \mathrm{I}$-glucagon (iodinated in our laboratory) were added to each plasma sample before chromatography. The radioactivity of the tracers present in the eluates $(<$ $300 \mathrm{cpm}$ ) represented a negible amount in the glucagon assay.

Eluates of $1.5 \mathrm{ml}$ were collected and counted for radioactivity in a gamma counter (Packard $800 \mathrm{C}$, Packard Instruments, Downers Grove, Illinois, USA). An aliquot ( 5 ul) was used for protein determination [ 9$]$ and the remainder stored at $-20^{\circ} \mathrm{C}$ for glucagon assay.

Analytical methods. Untreated plasma samples and eluates were assayed for glucagon immunoreactivity [10] with $30 \mathrm{~K}$ (C-terminal) and with R 8 ( N-terminal) antiserum, using crystalline porcine glucagon (Eli Lilly, Indianapolis, Indiana, USA) as a standard and for iodination [11]. The lower detection limit of $30 \mathrm{~K}$ was $2.5 \mathrm{pg}$, and that of $\mathrm{R} 8$ was $10 \mathrm{pg}$. The volume of plasma assayed with $30 \mathrm{~K}$ was $0.2 \mathrm{ml}$ and with R 8 was $0.1 \mathrm{ml}$, and the aliquot of eluate assayed with $30 \mathrm{~K}$ was $0.4 \mathrm{ml}$ and with $\mathrm{R} 8$ was $0.3 \mathrm{ml}$. The protein content of all the samples was brought up to the equivalent of $0.2 \mathrm{ml}$ of plasma by adding normal sheep serum immediately before adding the charcoal dextran mixture. R8 is a highly GLI cross-reacting antiserum [12] which detects the two major families of GLI from intestine (peak 1: $8000-12000$ daltons and peak 2: $\sim 3500$ daltons). In the R 8 assays isolated GLI peak 1 and GLI peak 2 from canine or human intestine diluted in a parallel fashion to crystalline porcine glucagon (Fig. 1). $30 \mathrm{~K}$ reacts negiblably with the glucagon fragment [1-21] but shows a substantial reaction with the C-terminal fragment [18-29], and reacts only weakly with intestinal extracts [13]. 


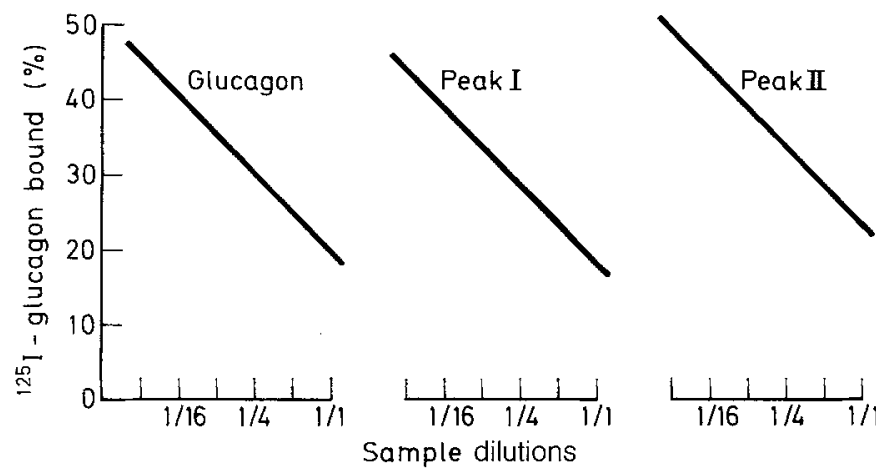

Fig. 1. Dilution slopes of GLI fractions (peaks I and II) from human and canine intestinal extracts and pork crystalline glucagon as detected by R-8 antiserum. Each line represents the superimposed slopes obtained with four different samples (for GLI fractions two samples were from human and two from canine extract) at serial dilutions in duplicate, the deviations from the slopes at any point was $< \pm 2 \%$ of ${ }^{125}$ I-glucagon bound
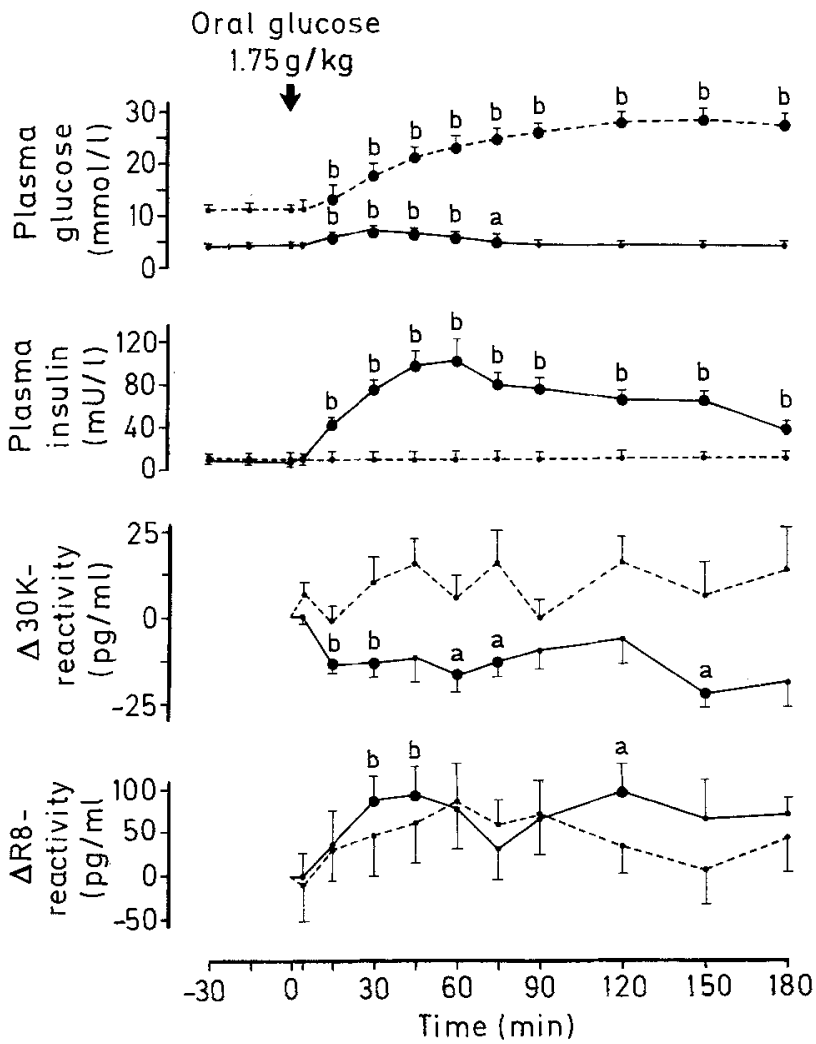

Fig. 2. Plasma glucose, insulin and variations from mean baseline of glucagon immunoreactivity (measured with a C-terminal antiserum: $30 \mathrm{~K}$, and with a GLI cross-reacting antiserum: R8) in 12 Type 1 diabetic patients (----, for insulin values $n=7$ ) and in 12 control subjects (-) during an oral glucose tolerance test (mean \pm SEM). The large dots represent statistically significant differences from the respective baseline values, ${ }^{\mathrm{a}} p<0.05,{ }^{\mathrm{b}} p<0.01$

Plasma insulin was determined by radioimmunoassay [14]. C-peptide was analyzed by a commercial radioimmunoassay kit (Daiichi Radioisotope Laboratories, Tokyo, Japan). Glucose was analyzed by a commercial glucose-oxidase preparation (Biochemica Test Combination, Boehringer, Mannheim, FRG).
Statistical analysis. Results are expressed as mean $\pm \mathrm{SEM}$ in $\mathrm{pg} / \mathrm{ml}$ of pancreatic glucagon equivalents and groups compared by Wilcoxon's rank sum test for paired and unpaired data.

\section{Results}

\section{Total plasma}

The mean plasma values for glucose, insulin, $30 \mathrm{~K}$ - and R8-reactivity from normal and diabetic subjects during the oral glucose tolerance test are shown in Figure 2. In the normal group, the mean basal plasma glucose levels $(4.4 \pm 0.1 \mathrm{mmol} / 1)$ increased to $5.6 \pm 0.3,7.0 \pm 0.4$, $6.6 \pm 0.5$ and $5.9 \pm 0.4(p<0.01)$ at $15,30,45$ and $60 \mathrm{~min}$, respectively, and to $5.2 \pm 0.4$ at $75 \mathrm{~min}$ after the glucose load $(p<0.05)$. In this group, the mean basal plasma insulin values $(9 \pm 1 \mathrm{mU} / \mathrm{l})$ increased significantly, $(p<$ 0.01 ) in all post-glucose samples reaching a maximum mean value of $104 \pm 19 \mathrm{mU} / 1$ at $60 \mathrm{~min}$. In the 11 normal subjects, the basal plasma $30 \mathrm{~K}$-reactivity ranged from 95 to $300 \mathrm{pg} / \mathrm{ml}$. In one subject the $30 \mathrm{~K}$-reactivity was as high as $1045 \mathrm{pg} / \mathrm{ml}$. After glucose, a decrease was observed in all subjects, reaching statistical significance $(p<0.01$ at 15 and $30 \mathrm{~min}$, and $p<0.05$ at 60,75 and $150 \mathrm{~min}$ ). In this group, plasma R 8-reactivity in the basal state ranged from 300 to $1100 \mathrm{pg} / \mathrm{ml}$ which significantly augmented at 30 and $45 \mathrm{~min}(p<0.01)$, and at $120 \mathrm{~min}(p<0.05)$ after the oral glucose load.

In the Type 1 diabetic patients, the mean basal plasma glucose level was $11.4 \pm 1.7 \mathrm{mmol} / 1$ which increased after the glucose load $(p<0.01)$, reaching a maximal value at $150 \mathrm{~min}(29.1 \pm 2.1 \mathrm{mmol} / 1)$. The plasma glucose concentrations in these patients were higher than in the normal subjects throughout the test $(p<0.01)$. The insulin assay performed in seven patients, and the C-peptide assay performed in the remaining five, because of the presence of insulin antibodies, showed a lack of $\beta$-cell response to glucose in all patients. After glucose, basal $30 \mathrm{~K}$-reactivity (range $85-550 \mathrm{pg} / \mathrm{ml}$ ) did not decrease. On the contrary, all patients exhibited a moderate increase, although it did not achieve statistical significance at any point during the test. Basal plasma R 8-reactivity (range $400-800 \mathrm{pg} / \mathrm{ml}$ ) was similar to that in normal subjects; it increased after glucose, although no significant changes were observed. No glucagon antibodies were detected in any subject.

\section{Plasma chromatography on Biogel P-30}

Up to four discrete peaks of glucagon immunoreactivity, with approximate molecular weights of $>20,000$, 9000,3500 , and 2000 , were detected with both antisera in normal subjects and in Type 1 diabetic patients, in basal and post-glucose plasma samples. The data are presented as the values with either antiserum for fraction I (eluates of the protein area), fraction II (following eluates up to the maximal peak of ${ }^{125}$ I-insulin), fraction III (following eluates up to the end of the ${ }^{125} \mathrm{I}$-glu- 
Table 2. Biogel P-30 plasma R8- and 30 K-reacting components in basal state and after an oral glucose load (1.75 g/ kg of body weight) in normal subjects and in Type 1 diabetic patients

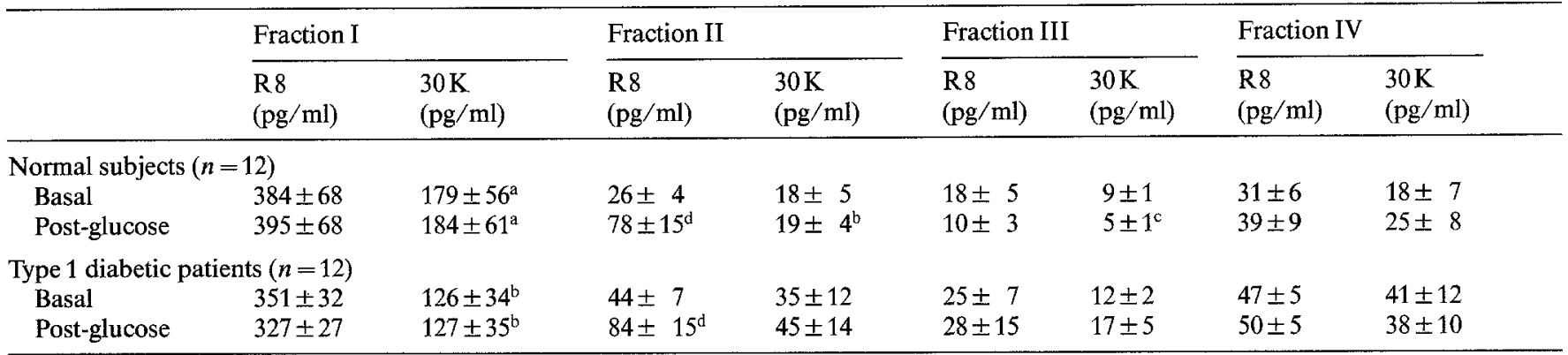

Results given as mean \pm SEM. ${ }^{\mathrm{a}} p<0.05,{ }^{\mathrm{b}} p<0.01$ for $\mathrm{R} 8$ versus $30 \mathrm{~K}$ values; ${ }^{\mathrm{c}} p<0.05,{ }^{\mathrm{d}} p<0.01$ for post-glucose versus basal values
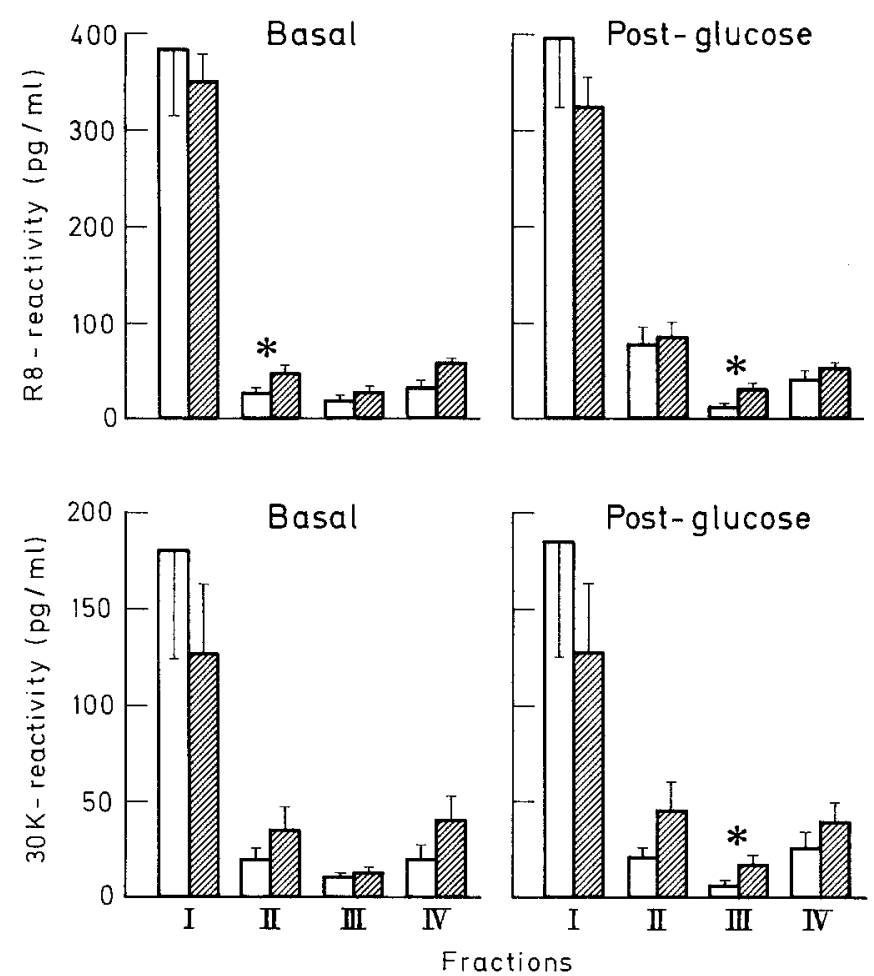

Fig. 3. Comparison of the Bio-gel P-30 plasma R8- and 30K-reacting components between 12 Type 1 diabetic patients (ש্A) and 12 normal subjects $\square$ in the basal state and after an oral glucose load $(1.75 \mathrm{~g} /$ $\mathrm{kg}$ body weight). Fraction I: $>20,000$; fraction II: $\sim 9,000$; fraction III: $\sim 3,500$ and fraction IV: $\sim 2,000 .{ }^{*} p<0.05$, statistically significant differences between both groups

cagon area) and fraction IV (following eluates up to the appearance of ${ }^{125} \mathrm{I}$ ). The values of each fraction were calculated as the sum of immunoreactivity present in the corresponding eluates $(1.5 \mathrm{ml})$ divided by the volume of the plasma loaded $(3 \mathrm{ml})$. The mean \pm SEM R8-reactivity recovered from the columns was $80 \pm$ $5.2 \%$ and that of $30 \mathrm{~K}$-reactivity was $88 \pm 4.2 \%$.

In normal subjects, most of the immunoreactivity of basal plasma detected with both antisera corresponded to fraction I (Table 2). In this fraction, the R8-reactivity ranged from 181 to $855 \mathrm{pg} / \mathrm{ml}$ and the 30 K-reactivity ranged from 45 to $758 \mathrm{pg} / \mathrm{ml}$; there was no correlation between individual $\mathrm{R} 8$ and $30 \mathrm{~K}$ values, although the
R8-reactivity was higher than $30 \mathrm{~K}$-reactivity in all except in the subject with the highest $30 \mathrm{~K}$ value, in whom the $\mathrm{R} 8$ value was half of that of $30 \mathrm{~K}$. Fraction I did not dilute in parallel with the glucagon standard with either antiserum. The R8-reactivities in fractions II, III and IV of basal plasma were not significantly different from their respective $30 \mathrm{~K}$ values. After glucose, fraction I still represented the highest percentage of the immunoreactivity detected with both antisera and it did not change from basal values. Fraction II had higher R 8than $30 \mathrm{~K}$-reactivities $(p<0.01)$ and in fractions III and IV the R8-values were similar to those of $30 \mathrm{~K}$, in postglucose plasma samples. When compared with basal values, the only significant change observed with $R 8$ antiserum was a threefold increase of the immunoreactivity in fraction II, while the R8-reactivities in fractions I, III and IV did not change. The $30 \mathrm{~K}$-reactivities in fraction III significantly decreased after glucose, while in fractions I, II and IV they did not change.

In Type 1 diabetic subjects, most of the immunoreactivity of basal plasma detected with both antisera was in fraction I (Table 2). The R8 values of this fraction (range $199-492 \mathrm{pg} / \mathrm{ml}$ ) were higher than their $30 \mathrm{~K}$ values (range $38-461 \mathrm{pg} / \mathrm{ml}$ ) in all except in the subject with the highest $30 \mathrm{~K}$ value; no correlation was found between individual $\mathrm{R} 8$ and $30 \mathrm{~K}$ values. In fractions II, III and IV, the R8-reactivities were similar to the respective $30 \mathrm{~K}$ values. After the oral glucose load, fraction I continued representing the largest percentage of the total immunoreactivity, and no change from basal was found with either antiserum. No significant differences were found between R 8 - and $30 \mathrm{~K}$-reactivities in fractions II, III and IV in post-glucose plasma samples. When compared with basal values the only significant change observed with $R 8$ antiserum was a twofold increase of the immunoreactivity in fraction II. No significant changes were detected with $30 \mathrm{~K}$ antiserum in the four fractions, although in seven out of the 12 patients the $30 \mathrm{~K}$-reactivities in fractions II and III were higher after the glucose load.

In basal plasma, the R8-reactivities in fractions I, III and IV showed no differences between the two groups, while in fraction II they were higher in the diabetic group ( $44 \pm 7$ versus $24 \pm 4 \mathrm{pg} / \mathrm{ml}, p<0.05$, Fig. 3). 
The $30 \mathrm{~K}$-reactivities in the four fractions of basal plasma from diabetic patients did not differ significantly from those of control subjects. In post-glucose plasma samples, the R8- and 30K-reactivities in fraction III were higher in the diabetic patients $(28 \pm 15$ versus $10 \pm 3 \mathrm{pg} / \mathrm{ml}, p<0.05$ and $17 \pm 5$ versus $5 \pm 1 \mathrm{pg} / \mathrm{ml}$, $p<0.05$, respectively), while no differences were observed in fractions II and IV between diabetic and control subjects after glucose.

\section{Plasma GLI response to oral glucose}

The R8-reactivity increased significantly after the glucose load only in fraction II (diabetic $40 \pm 12 \mathrm{pg} / \mathrm{ml}$, control subjects $52 \pm 17 \mathrm{pg} / \mathrm{ml}, p<0.01$ ). The $\mathrm{R} 8$ minus $30 \mathrm{~K}(\mathrm{R} 8-30 \mathrm{~K})$ value of this fraction increased after glucose (diabetics $8 \pm 14$ to $39 \pm 19 \mathrm{pg} / \mathrm{ml}, p<0.05$; controls $8 \pm 6$ to $59 \pm 14 \mathrm{pg} / \mathrm{ml}, p<0.01$ ), while no significant changes were observed in $\mathrm{R} 8-30 \mathrm{~K}$ value of the other three fractions in either group. The difference between the post-glucose variations of $\mathrm{R} 8$ - and $30 \mathrm{~K}$-reactivity $(\Delta \mathrm{R} 8-\Delta 30 \mathrm{~K})$ in fraction II was $30 \pm 12(p<0.05)$ and $51 \pm 15 \mathrm{pg} / \mathrm{ml}(p<0.01)$ in diabetic and control subjects, respectively. No statistical difference between the two groups was observed in any of the above calculated values.

\section{Discussion}

In normal subjects plasma glucagon immunoreactivity detected with $30 \mathrm{~K}$ decreased after glucose. The gel filtration of basal plasma revealed the four immunoreactive glucagon (IRG) components described previously, $\mathrm{IRG}^{>20000}$ or big plasma glucagon, IRG ${ }^{9000}, \mathrm{IRG}^{3500}$ and $\mathrm{IRG}^{2000}$ [15]. After glucose, only IRG ${ }^{3500}$ (fraction III) decreased significantly, while no changes were observed in the other three components. Big plasma glucagon (fraction I) represented the largest percentage of the total immunoreactivity, and as already described [15], exhibited a wide range of concentrations in the normal subjects. When total plasma is assayed for glucagon immunoreactivity, big plasma glucagon may be responsible for levels that are comparable with those present in patients with glucagonoma [8]. This was the case in the normal subject with $1045 \mathrm{pg} / \mathrm{ml}$ total plasma glucagon, most of it being big plasma glucagon. The nature of this fraction is still unclear. Due to the fact that big plasma glucagon does not dilute in parallel to glucagon standard, care was taken to load the column with the same volume of basal and post-glucose plasma samples. Although variations in big plasma glucagon were observed between basal and post-glucose chromatographies from the same individual, they did not achieve statistical significance. In the case of the normal group, these variations resulted in a higher mean big plasma glucagon value after glucose, which contributed to a slightly higher post-glucose glucagon immunoreactivity when the values of the four IRG fractions were summed up, reversing the post-glucose decrease of glucagon immunoreactivity observed when total plasma was assayed. A higher, although not significant, mean post-glucose IRG $^{2000}$ value contributed to this reversal effect also. Studies of serial dilutions of this plasma component have not been performed because it is always present in small concentrations. Plasma IRG ${ }^{3500}$, isolated by gel filtration from normal subjects during an arginine infusion, and plasma IRG ${ }^{9000}$, from a patient with glucogonoma and chronic renal failure patients, diluted in parallel to the glucagon standard (I. Valverde, personal communication), and after re-chromatography their recoveries from the column ranged from 90 to $100 \%$.

In Type 1 diabetic patients basal plasma IRG values did not decrease after oral glucose. In most patients, the post-glucose levels were higher than the basal value at some time during the test. Plasma gel filtration revealed that the basal values in the four IRG fractions were similar to those in the normal subjects. After a glucose load, there was no suppression of the basal IRG ${ }^{3500}$ plasma level, and in some patients an increase was observed. The paradoxical rise of total IRG may be due to $I_{R G}{ }^{3500}$ and IRG ${ }^{9000}$, which also increased in those patients.

In this Type 1 diabetic group true hyperglucagonaemia was found relative to plasma glucose concentrations, due to the fact that basal IRG ${ }^{3500}$ values in diabetic patients are higher than post-glucose $I R G^{3500}$ values in normal subjects, while plasma glucose levels are higher in basal samples from diabetic than in post-glucose samples from control subjects. These results validate the concept of relative hyperglucagonaemia [16]. The circulating IRG ${ }^{9000}$ is considered to be the homologue of that of the same molecular weight found in pancreatic extracts [17]. This C-terminal glucagon peptide could well be part of the pre-proglucagon molecule, the structure of which was recently predicted from the sequence of cloned cDNA [18], but its exact participation in the biosynthetic process is not clear. Plasma $\mathrm{IRG}^{9000}$ has been reported to be elevated in various situations of sustained hyperactivity of the A cell and of impaired catabolism of this component $[8,19]$. In this group of diabetic subjects, the mean plasma levels of IRG $^{9000}$ were close to $100 \%$ higher than those in normal subjects.

With the gut-GLI-reacting antiserum, $\mathrm{R} 8$, a significant increase in total GLI was observed only in some post-glucose plasma samples of the normal subjects. In both groups chromatographied plasma, assayed with R8 antiserum, exhibited four glucagon immunoreactive peaks in the same molecular weight regions as those detected with the $\mathrm{C}$-terminal $30 \mathrm{~K}$ antiserum. The R8-reactivity in fraction I, which represented the highest percentage of total plasma immunoreactivity, did not correlate with the big plasma glucagon values and was not affected by the glucose load; its nature was not 
studied further. In both groups after oral glucose administration, the R8-reactivity and the $\mathrm{R} 8-30 \mathrm{~K}$ value increased only in fraction II, indicating that GLI peptide(s) of molecular weight(s) between $>6,000$ and $<$ 20,000 are the one(s) secreted in response to the glucose load. Peptides close to these molecular weights have been extracted from human [20], canine [21], rabbit [22] and porcine [23] intestines. Similar results have been obtained in dogs $[12,24]$, although in this animal the increment of R8-reactivity of fraction II was much higher than in our normal human group. A greater response of GLI to oral glucose was also observed in gastrectomized patients [25-27] and the massive exposure of the intestine to the sugar could be the cause of the increased secretion of GLI in both cases. The R8-reactivity in fraction II of basal plasma was higher in diabetic than in control subjects, but the $\mathrm{R} 8-30 \mathrm{~K}$ values of this fraction were similar in both groups, due to the higher IRG $^{9000}$ values in the diabetic patients, indicating no difference in basal GLI peptides of this size in either group. After glucose the IRG ${ }^{9000}$ increased in some diabetic patients and to evaluate the GLI secretion this should be taken into account. The post-glucose $\Delta \mathrm{R} 8-\Delta 30 \mathrm{~K}$ values in fraction II were similar in the diabetic and control groups, suggesting a normal GLI response to glucose in diabetic patients. These results are in disagreement with two previous reports on Type 1 diabetic subjects. Heding and Rasmussen [3] evaluated GLI secretion in total plasma as the response to oral glucose detected with an $\mathrm{N}$-terminal glucagon-reacting antiserum, and Matsuyama et al. [7] measured basal and post-breakfast GLI as the difference between the values obtained with $\mathrm{N}$ - and $\mathrm{C}$-terminal glucagon-reacting antiserum. In the diabetic groups of both studies, GLI presented a significantly higher value compared with normal subjects. From our chromatographic data, the complexity of peptides reacting with one or both antisera is clear. This complexity impedes evaluation of the levels of GLI in total plasma even after oral glucose. To date, the only way to measure plasma GLI is by gel chromatography and subsequent assay with two types of glucagon antisera. Even though we are assuming the $\mathrm{IRG}^{9000}$ reacts equally with both antisera used, this fact cannot be proven until a pure preparation of this C-terminal glucagon peptide is available.

Two GLI peptides from porcine intestine have been purified and named glicentin [23] and oxyntomodulin [28]. Both peptides contain glucagon within their structure and they seem to be part of the pre-proglucagon molecule [18]. The molecular size of glicentin $(8000 \Delta)$ is included in that of plasma fraction II and it might represent secreted GLI after glucose. Although antibodies specific to glicentin have been obtained, which do not react with glucagon, their capacity for measuring glicentin in plasma has not yet been documented fully [29]. The molecular size of oxyntomodulin [28] corresponds with that of gut-GLI peak II $[21,30]$ and is included in that of plasma fraction III, but circulating
GLI peptides of this size were not increased after oral glucose either in this study or in dogs [12].

Acknowledgments. We wish to express our thanks to Drs. R. H. Unger and M.L. Villanueva for their generous gifts of anti-glucagon sera and to Dr. R. E. Chance for crystalline porcine glucagon. Our thanks also go to Ms. G.Calvo for her expert technical assistance and to Ms. L. Gulliksen for typing the manuscript. This work was supported in part by the Fundación Conchita Rábago de Jiménez Díaz, Madrid. Part of this work was presented at the 11th Congress of the International Diabetes Federation, Nairobi, Kenya, 1982.

\section{References}

1. Muller WA, Faloona GR, Aguilar-Parada E, Unger RH (1970) Abnormal alpha-cell function in diabetes: response to carbohydrate and protein ingestion. N Engl J Med 283: 109-115

2. Buchanan KD, McCarroll AM (1972) Abnormalities of glucagon metabolism in untreated diabetes mellitus. Lancet 2:1394-1395

3. Heding LG, Rasmussen SM (1972) Determination of pancreatic and gut glucagon-like immunoreactivity in normal and diabetic subjects. Diabetologia 8: 408-411

4. Day JL, Anderson JA (1973) Abnormalities of glucagon metabolism in diabetes mellitus. Clin Endocrinol 2: 211-217

5. Kurahachi H, Seino Y, Ikeda M, Sakurai H, Yoshimi T, Imura H (1977) Insuppressibility of plasma glucagon by orally or intravenously administered glucose in diabetes mellitus. Endocrinol Japon 24 (5): 413-419

6. Aydin I, Raskin P, Unger RH (1977) The effect of short-term intravenous insulin administration on the glucagon response to a carbohydrate meal in adult onset and juvenile type diabetes. Diabetologia 13: 629-636

7. Matsuyama T, Hoffman WH, Dunbar JC, Foà NL, Fòa PP (1975) Glucose, insulin, pancreatic glucagon and glucagon-like immunoreactive materials in the plasma of normal and diabetic children. Effect of the initial insulin treatment. Horm Metab Res 7:452-456

8. Valverde I (1983) Heterogeneity of circulating glucagon and glucagon-like immunoreactivity. In: Lefebvre PJ (ed) Glucagon I. Handbook of experimental pharmacology 66: I, Springer, Berlin Heidelberg New York Tokyo, pp 223-244

9. Lowry OH, Rosebrough NJ, Farr AL, Randall RJ (1951) Protein measurement with the folin phenol reagent. J Biol Chem 193: 265-275

10. Faloona GR, Unger RH (1974) Glucagon. In: Jaffe BM, Behrman HR (eds) Methods of hormone radioimmunoassay. Academic Press, New York, pp 317-320

11. Jörgensen KH, Larsen UD (1972) Purification of ${ }^{125} \mathrm{I}$-glucagon by anion exchange chromatography. Horm Metab Res 4: 223-224

12. Valverde I, Ghiglione M, Matesanz R, Casado S (1979) Chromatographic pattern of gut glucagon-like immunoreactivity (GLI) in plasma before and during glucose absorption. Horm Metab Res 11: $343-346$

13. Faloona GR (1972) The structure-function relationships of pancreatic glucagon. In: Lefebvre PJ, Unger RH (eds) Glucagon: mo* lecular physiology, clinical and therapeutic implications. Pergamon Press, Oxford, New York, Toronto, Sydney, Braunschweig, pp 201-204

14. Herbert V, Lau K-S, Gottlieb CW, Bleicher SJ (1965) Coated charcoal immunoassay of insulin. J Clin Endocrinol Metab 25: $1375-1384$

15. Valverde I, Villanueva ML, Lozano I, Marco J (1974) Presence of glucagon immunoreactivity in the globulin fraction of human plasma ("big plasma glucagon"). J Clin Endocrinol Metab 39: 1090-1098

16. Unger RH, Aguilar-Parada E, Muller WA, Eisentraut AM (1970) Studies of pancreatic alpha-cell function in normal and diabetic subjects. J Clin Invest 49: 837-848 
17. Rigopoulou D, Valverde I, Marco J, Faloona G, Unger RH (1970) Large glucagon immunoreactivity in extracts of pancreas. J Biol Chem 245: 496-501

18. Bell GI, Sanchez-Pescador R, Laybourn PJ, Najarian RC (1983) Exon duplication and divergence in the human preproglucagon gene. Nature 304: 368-371

19. Jaspan JB, Rubenstein AH (1977) Circulating glucagon. Plasma profiles and metabolism in health and disease. Diabetes 26: 887-904

20. Valverde I, Villanueva ML, Lozano I, Roman D, Diaz-Fierros M, Marco J (1973) Chromatographic pattern of human intestinal glucagon-like immunoreactivity. J Clin Endocrinol Metab 36: 185-187

21. Valverde I, Rigopoulou D, Marco J, Faloona GR, Unger RH (1970) Characterization of glucagon-like immunoreactivity. Diabetes 19: 614-623

22. Tager HS, Markese J (1979) Intestinal and pancreatic glucagonlike polypeptides. Evidence for identity of higher molecular weight forms. J Biol Chem 254: 2229-2233

23. Thim L, Moody AJ (1981) The primary structure of porcine glicentin (proglucagon). Regul Peptides 2: 139-150

24. Rovira A, López-Novoa JM, Zubiaur M, Matesanz R, Ghiglione M, Pascual JM, Valverde I (1982) Renal metabolism of gut glucagon like immunoreactivity. Endocrinology 110: 2030-2036

25. Marco J, Baroja IM, Diaz-Fierros M, Villanueva ML, Valverde I (1972) Relationship between insulin and gut glucagon-like immunoreactivity secretion in normal and gastrectomized subjects. $\mathbf{J}$ Clin Endocrinol Metab 34: 188-191
26. Shima K, Kuroda K, Matsuyama T, Tarni S, Nishikawa M (1972) Plasma glucagon and insulin responses to various sugars in gastrectomized subjects. Proc Soc Exp Biol Med 139: 1042-1048

27. Bloom SR, Royston C, Thomson J (1972) Enteroglucagon release in the dumping syndrome. Lancet $2: 788-791$

28. Bataille D, Gespach C, Tatemoto K, Marie J-C, Coudray A-M, Rosselin G, Mutt V (1981) Bioactive enteroglucagon (oxyntomodulin): present knowledge on its chemical structure and its biological activities. Peptides 2 (Suppl 2): 41-44

29. Moody AJ, Sundby F, Jacobsen H (1978) The tissue distribution and plasma levels of glicentin (gut GLI-I). Scand J Gastroenterology 13 (Suppl 49): 127 (Abstract)

30. Holst JJ (1982) Evidence that enteroglucagon (II) is identical with the C-terminal sequence (residues 33-69) of glicentin. Biochem J 207: $381-388$

Received: 19 March 1984

and in revised form: 10 December 1984

Dr. Isabel Valverde

Dpto Metabolismo, Nutrición y Hormonas

Fundación Jiménez Díaz

Avda Reyes Católicos 2

E-28040 Madrid

Spain 